\title{
TEORI PERSEPSI MULLÂ SHADRÂ BESERTA IMPLIKASI EPISTEMOLOGI DAN METODOLOGISNYA UNTUK PSIKOLOGI ${ }^{1}$
}

\author{
Husain Heriyanto \\ Sadra International Institute Jakarta; Program Pascasarjana Universitas Indonesia; \\ the Islamic College for Advanced Studies (ICAS) Jakarta; the Avicenna Center for Religion and \\ Science Studies (ACRoSS) \\ Diterima tanggal 15 Agustus 2015 / Disetujui tanggal 15 Oktober 2015
}

\begin{abstract}
Human action is seen as behavior of organisms that are subject to the law of effect (the law of effect) through the process of reinforcement and punishment, stimulus-response mechanism, learning by trial, and the laws of Biochemistry and physiological. Mulla Shadrâ has brought us to a new consciousness that we are over this as if asleep because it doesn't realize that all our actions including sensory perception is our soul's activity directly. Epistemolois and methodological implications of the theory of perception Shadrâ this potentially to do a revolution in psychology, that relives live, i.e. as a single agent - holistic in all the actions of our perception and cognition
\end{abstract}

Kata kunci: Epistemologi, persepsi indrawi, tunggal-holistik.

\section{Pendahuluan}

Buku "Saatnya Aku Belajar Pacaran" menuai kontroversi dan reaksi yang tajam.Buku yang ditulis oleh pengajar psikologi Toge Aprilianto tersebut menganjurkan anak-anak muda yang berpacaran untuk mempraktekkan seks pra-nikah. Menurut Toge, wajar rasanya bila pacar mengajak pasangannya untuk ML. "Hal itu `kan alamiah, naluriah. Jadi, itu justru pertanda kalau kamu dan / atau pacarmu masib punya energi buat terlibat dalam proses reproduksi, yang memang sewajarnya dimiliki oleh tiap mabluk bidup,"tulis Toge. Karena kandungan isinya yang dianggap bertentangan dengan norma agama, moral dan prinsip pendidikan, buku tersebut akhirnya dilarang terbit dan ditarik dari peredaran. Mengapa seorang ahli psikologi menganjurkan perbuatan yang jelas-jelas bertentangan dengan ajaran agama dan norma susila? Dia berargumen bahwa dorongan melakukan hubungan seksual adalah alamiah dan naluriah sehingga dianggap sah dan normal saja mempraktekkan seks pra-nikah.

Di sini kita bisa mengajukan serangkaian pertanyaan: apa yang dimaksudkan dengan dorongan naluriah? Agaknya yang dimaksudkan dorongan naluriah itu adalah dorongan biologis. $\mathrm{Nah}$, apakah karena ia merupakan dorongan biologis maka ia harus dipenuhi? Bagaimana halnya dengan kesadaran moral yang menolak tindakan asusila tersebut?Bukankah kesadaran moral juga termasuk dorongan alamiah yang lebih mendasar?Lalu, mengapa dorongan alamiah

${ }^{1}$ Paper ini dipresentasikan pada Seminar Nasional "Epistemology for Islamic Psychology", yang sekaligus merupakan rangkaian seminar keenam pra-konferensi IC-THuSI, melalui kerjasama Fakultas Ushuluddin and Humaniora IAIN Antasari Banjarmasin, Sadra International Institute dan Asosiasi Psikologi Islam di Banjarmasin, 19-20 Agustus 2015. 
yang lebih terkait dengan nilai moral dan harkat kemanusiaan dianggap kurang penting dan justru mengutamakan dorongan biologis? Jika kita selidiki lebih lanjut, jelaslah bahwa sang penulis memiliki asumsi-asumsi yang melambari pendapatnya yang tertuang dalam buku tersebut. Setidaknya ada beberapa asumsi (pandangan dasar; pra-pemahaman), yaitu:

1. Bahwa dorongan biologis lebih utama dan penting daripada kesadaran moral

2. Bahwa kesadaran moral tidak diperhitungkan sebagai faktor yang mempengaruhi perilaku manusia

3. Perilaku manusia lebih ditentukan oleh dorongan-dorongan biologis

4. Perilaku manusia bisa dikontrol melalui mekanisme stimulus-response ( $S$-Rdoctrine) yang bekerja menurut prinsip-prinsip kimiawi-biologis.

5. Hakekatnya manusia tidak lebih dari hewan; manusia hanya lebih kompleks dan rumit daripada hewan secara kuantitatif.

Tentu saja, asumsi-asumsi sang penulis tidaklah muncul begitu saja. Sebagai dosen psikologi, dia tentunya belajar dan menekuni psikologi yang umumnya dipengaruhi oleh pandangan dunia Barat modern mainstream yang bercorak positivistik dan materialistik.Banyak aliran psikologi yang mengadopsi pandangandunia materialistik tersebut dengan berbagai varian seperti behaviorisme (Edward Thorndike, B. F. Skinner, Ivan Pavlov, John B. Watson), psikoanalisis Freud (Sigmund Frued, Alfred Adler), strukturalisme (Wundt), dan fungsionalisme (pengaruh Darwin). Dalam behaviorisme, perilaku manusia hanya dilihat dari aspek yang bisa diobservasi secara fisik-biologis dengan menggunakan pendekatan kuantitatif dan menganggap bahwa segenap proses mental dan kognisi yang tak bisa diobservasi secara empiris adalah di luar wilayah psikologi dan dianggap tidak ilmiah.

Tindakan manusia dipandang sebagai perilaku organisme yang tunduk pada hukum efek (the law of effect) melalui proses reinforcement dan punishment, mekanisme stimulus-responses, learningby trial, dan hukum-hukum biokimiawi dan fisiologis. Itu sebabnya para tokoh behavioristik kerap menggunakan berbagai hewan seperti kucing, anjing, tikus dan monyet untuk mempelajari cara bekerja otak dan perilaku manusia. Thorndike memakai kucing untuk menemukan prinsip belajar yang disebutnya "learning by trial", 2 sedangkan Pavlov memakai anjing untuk menjelaskan kemunculan konsep sebab-akibat sebagai asosiasi yang terbentuk oleh stimulus dan respons. ${ }^{3}$ Sementara itu, dalam perspektif psikoanalisis Freud, perilaku manusia sepenuhnya didorong dan digerakkan oleh insting biologis.

Energi psikis manusia berasal dari apa yang disebutnya $i d$, yaitu hasrat libido seksual sebagai sumber primer motivasi manusia berperilaku. Adapun diri yang disebutnya sebagai ego berperan untuk mengontrol keinginan-keinginan $i d$.Dan struktur ketiga yang disebut superego berperan untuk internalisasi aturan-aturan dan batasan-batasan dari luar/masyarakat sehingga terjadi adaptasi perilaku.Ketiga struktur itu bekerja sesuai dengan -dan tunduk pada- mekanisme hukum-hukum biologis, kimiawi, dan fisiologis. ${ }^{4}$

Terkait dengan gangguan-gangguan psikologis yang terjadi (psychological disorder, neurosis) Freud menyebutnya sebagai efek dari tidak terlampiaskannya dorongan-dorongan.Libido

${ }^{2}$ Lihat Neil R. Carlson, Psychology: The Science of Behavior (Massachusetts: Allyn and Bacon, 1993), 13.

${ }^{3}$ Carlson, Psychology: The Science of Behavior, 14 .

${ }^{4}$ Carlson, Psychology: The Science of Behavior, 479-481. 
ataupun insting agresif lantaran larangan-larangan dan aturan-aturan masyarakat.Dia mengintroduksi berbagai bentuk mekanisme pertahanan (defensemechanisms) akibat tak tersalurkannya libido dan agresivitas tersebut dengan istilah-istilah represi, formasi reaksi, proyeksi, sublimasi, rasionalisasi, dan konversi. ${ }^{5}$ Yang sungguh menggelikan sekaligus menjijikkan adalah bagaimana Freud berkesimpulan bahwa agama adalah produk neurosis dan kebudayaan-peradaban manusia adalah sublimasi dari hasrat-hasrat libido seksual (semacam pengalihan energi seksual kepada energi mental).

Betapa rendahnya pandangan Freud terhadap manusia! Nah, kembali kepada Toge, sang penulis buku provokatif di muka, kita dapat menyimpulkan bahwa pemikiran dan pendapatnya yang tertuang dalam buku tersebut merupakan buah pembacaannya terhadap aliran-aliran psikologi yang menempatkan manusia tidak lebih sebagai hewan kompleks dengan dorongan libido yang menjadi sumber energi motivasi dan perilaku. Buku itu hanyalah salah satu bukti konkrit bagaimana pandangan materialistik dan positivistik sangat berpengaruh terhadap cara pandang para sarjana kita termasuk dalam bidang psikologi. Meskipun telah muncul aliranaliran psikologi yang mengkritik behaviorisme atau psikoanalisis Freudian seperti mazhab-mazhab humanisme (Abraham Maslow, Carl Rogers), eksistensialisme (Ludwig Binswanger, Rollo May), dan psikologi kognitif (Jean Piaget, Jerome Bruner) ${ }^{6}$, rupanya pandangan mekanistik-materialistik masih kuat tertancap dalam cara berpikir para akademisi dan sarjana kita dalam memahami tindakan dan perilaku manusia.

Fakta ini sekaligus sebuah tantangan yang nyata bagi sarjana Muslim untuk berkontribusi membangun paradigma ilmu psikologi yang lebih humanistik, holistik, dan berdimensi spiritualtransendental.Tugas ilmiah sekaligus tanggung jawab moral kemanusiaan ini, tentu saja, dimulai dari usaha menggali-kembangkan kapasitas pandangan-dunia Islam sebagai kerangka kerja dan basis pembentukan paradigma psikologi yang non-positivistik tersebut. Kerangka kerja ilmiah tersebut tidak lain adalah konstruksi dasar pemetaan ilmu, yaitu kajian epistemologi. Di sinilah letak urgensi dan pentingnya pembahasan "Epistemology for IslamicPsychology" ini.

\section{Status dan Tujuan Pokok Ilmu Psikologi}

Sejak istilah psikologi digunakan pertama kali oleh Wilhelm Wundt (w. 1920), melalui karyanya Principles of Physiological Psychology yang menjadi buku teks psikologi pertama, ilmu psikologi dibangun dan dikembangkan untuk memahami dan menjelaskan seluk beluk mengenai tindakan dan perilaku manusia.Yang dimaksudkan dengan kata "menjelaskan" (explanation) adalah usaha penyelidikan analisis untuk menemukan faktor-faktor penyebab suatu perilaku.Para psikolog mengklaim bahwa jika mereka dapat mendeskripsikan peristiwa-peristiwa yang menyebabkan suatu perilaku, maka hal itu dikatakan mereka telah menjelaskannya.Karena penekanan utama pada usaha memahami dan menjelaskan perilaku dengan metode ilmiah, maka sejumlah sarjana mendefinisikan psikologi sebagai sains perilaku (science of behavior). ${ }^{7}$

Dalam definisi yang lebih luas, Robert S. Feldman menulis, "Psikologi adalah sebuah studi ilmiah terhadap perilaku dan proses-proses mental, yang tidak hanya meliputi apa yang dilakukan

${ }^{5}$ Carlson, Psychology: The Science of Behavior, 481-482.

${ }^{6}$ Baca Michael W. Eysenck, Principles of Cognitive Psychology (East Sussex: Psychology Press, 2001), 271.

${ }^{7}$ Definisi ini pun dipakai oleh Neil R. Carlson sebagai judul bukunya, Psychology: The Science of Behavior (1993). 
orang tetapi juga aktivitas-aktivitas biologis, perasaan, persepsi, memori, mimpi, motivasi, penalaran, dan pemikiran mereka." ${ }^{\prime}$ Feldman melanjutkan bahwa para psikolog mencoba untuk mendeskripsikan, memprediksi, dan menjelaskan perilaku dan proses mental manusia sebagaimana juga membantu mengubah dan memperbaiki kehidupan orang-orang dan dunia tempat tinggal mereka. Persoalannya adalah sejauh manakah keberhasilan psikologi melakukan apa yang mereka klaim: memahami dan menjelaskan perilaku manusia beserta prosesproses mental yang berlangsung? Benarkah para psikolog telah merekomendasikan tindakan-tindakan yang menyehatkan mental manusia? Apakah psikologi yangmainstream telah berhasil membantu orang-orang mencapai kebahagiaan? Apakah penulis buku "Saatnya Aku Belajar Pacaran", Toge Apriliano-psikolog yang menganjurkan tindakan yang bertentangan dengan nilai agama dan kemanusiaan, hanya sebuah perkecualian ataukah memang menggambarkan kondisi umum secara implisit di kalangan sarjana psikolog kontemporer? Ada adagium, "psikolog banyak berbicara tentang kesehatan mental dankebahagiaan tetapi mental mereka sendiri rapub dan mereka umumnya tidak berbahagiakarena ilmunya".

Seorang tokoh akademisi Indonesia, profesor filsafat yang sebelumnya juga menekuni studi psikologi, yaitu Prof. Dr. Toeti Heraty Rooseno, dalam beberapa kesempatan berkata, "Psikolog memang cakap untuk menasehati orang lain tetapi tidakuntuk diri sendiri”. Ungkapan-ungkapan ini di satu sisi secara ekspisit merupakan reaksi kritis terhadap klaim-klaim psikologi yang mengaku telah memahami perilaku manusia beserta proses-proses mental yang terjadi, dan di lain sisi secara implisit hendak mengungkap kondisi aktual psikologi kontemporer, yaitu tengah menghadapi krisis eksistensial. Yang dimaksud krisis eksistensial di sini adalah para psikolog itu sendiri tidak meyakini teori-teori dan metode-metode terapi yang mereka ajarkan dan terapkan kepada masyarakat dan pasien mereka.Jika mereka sungguh-sungguh meyakini teoriteori yang menjelaskan perilaku manusia beserta proses-proses mental yang terjadi, tentu mereka pertama-tama menggunakannya untuk diri mereka sendiri baik dalam bentuk melakukan tindakan-tindakan yang membawa kesehatan mental dan kebahagiaan maupun dalam bentuk menghindari tindakan-tindakan yang berefek sebaliknya.

Berikut adalah sebuah kisah yang diangkat dari diskusi sebuah seminar prakonferensi ICTHuSI di Fakultas Psikologi Universitas Indonesia, Jakarta, sekitar dua bulan lalu, ${ }^{9}$ dengan kehadiran para profesor dalam psikologi, sosiologi dan filsafat. Sebagai responden ahli dalam seminar bertemakan "Emergensi dan Kreativitas: Tinjauan Filsafat, Tasawnf, Psikologi, dan Sosiologi", Prof. Dr. Hamdi Muluk - seorang guru besar psikologi Universitas Indonesia- mengajukan sejumlah pertanyaan kritis, dan bukan sekedar kritis tetapi sebuah gugatan tajam, yakni menggugat jati diri ilmunya sendiri, sebuah ilmu yang telah mengantarkannya menjadi seorang guru besar di perguruan tinggi ternama di negeri ini, yang telah mengharumkan namanya di masyarakat dan dunia sosial politik sebagai pakar psikologi dan peneliti ulung tentang persepsi publik..

Namun, hal itu semua tidakmembuatnya kehilangan daya kritisnya dan kejujuran ilmiahnya. Dia berkata, "Ada keanehan yang luar biasa dalam psikologi, yaitu kesadaran mempelajari

\footnotetext{
${ }^{8}$ Baca Robert S. Feldman, Essentials of Understanding Psychology (New York: McGraw-Hill, 2005), 5.

${ }^{9}$ Tepatnya pada 11 Juni 2015 di Fakultas Psikologi, Universitas Indonesia, Depok. Seminar ini merupakan seminar ketiga pra-konferensi IC-THuSI dengan tema Emergensi dan Kreativitas: Tinjauan Filsafat, Tasawuf, Psikologi, dan Sosiologi dengan para pembicara Dr. Husain Heriyanto, Dr. Ammar Fauzi, Dr. Bagus Takwin, dan Dr. Roby Muhammad.
} 
kesadaran.Ini sangat aneh, kenapa?Masak kesadaran hendak memahami dan menjelaskan kesadaran, ini bagaimana? Kan muter-muter saja, ia memahami dirinya sendiri, itu kan bukan pengetahuan namanya ..! Banyak lagi yang tak jelas dalam ilmu psikologi, misalnya pengertian "psyche" sebagai kata dasar psikologi itu apa, apakah mengacu "soul' atau "mind" atau apa? Lalu, karena mempelajari hal itu susah, maka kita dalam psikologi akhirnya mempelajari "perilaku" saja karena bisa diobservasi. Tapi, kalau kita pikirkan lebih dalam, apakah makna "perilaku" itu sendiri?Apa yang mendorong orang berperilaku tertentu dan mengapa berbedabeda di antara orang dengan lingkungan yang sama? Jadi, sebenarnya banyak tak jelas dalam psikologi. Orang luar melihat kami mantap karena banyak produk riset dan eksperimen kami terpublikasi secara luas sebagai aktivitas ilmiah dan sebagainya.Padahal dalam diri kami, dapur ilmu psikologi sendiri, kami ini keropos. Ya, kami enjoy saja menikmati itu meski di dalam kami rapuh, berantakan.

Maksudnya, konsep-konsep dasar ilmu psikologi itu sebenarnya banyak yang tidak jelas ..! Untung yang hadir di sini para dosen dan mahasiswa pascasarjana ya, yang sudah relatif matang... kalau mahasiswa S1 yang dengar ini, mungkin mereka pada kabur keluar dari psikologi.. ha.ha.." Analisis otokritis dan gugatan tajam Prof. Hamdi Muluk yang tergambar di muka merupakan salah satu etos keilmuan yang beliau miliki sebagai ilmuwan yang jujur, berbicara lugas apa adanya.

Dan beliau juga mengutarakannya dalam konteks yang tepat, yaitu di hadapan para akademisi, profesor (diantaranya Prof. Dr. Toeti Heraty), doktor berbagai bidang studi (psikologi, filsafat, sosiologi, ekonomi, matematikakomputasi, dan lingkungan).Secara tak semena-mena, beliau juga secara implisit mengarahkan pertanyaan kritis tersebut kepada saya sebagai presenter yang mewakili perspektif filsafat dalam seminar tersebut.Tentu saja, pernyataan-pernyataan kritis Prof. Hamdi Muluk tersebut merupakan hal-hal yang mendasar dan juga menjadi tugas filsafat untuk memberikan jawaban atau setidaknya semacam klarifikasi. Sesungguhnya pernyataan-pernyataan Prof. Hamdi Muluk bahwa "mengapa kesadaran mempelajari kesadaran", "kesadaran memahami kesadaran adalah seperti lingkaran", dan "tindakan kesadaran memahami dirinya sendiri bukanlah termasuk pengetahuan" adalah proposisi atau pertanyaan filosofis, yang sudah di luar kapasitas ilmu psikologi untuk menjawabnya.

Ini sekaligus menunjukkan bahwa setiap disiplin ilmu membutuhkan filsafat sebagai dasar kerangka kerja ilmunya.Konsep-konsep dasar setiap disiplin ilmu memerlukan penjelasan filsafat agar mengetahui asumsi-asumsi dasar yang melandasi seluruh bangunan teori dan metodologi disiplin ilmu tersebut.Oleh karena itu, psikologi tentu tidak diharapkan - dan juga memang tidak bisa - menjawab atau mengklarifikasi catatan-catatan kritis guru besar psikologi UI tersebut.Mari kita analisis dan uraikan pernyataan-pernyataan tersebut secara filosofis.

Klarifikasi ini sekaligus merupakan pintu masuk kita kepada pembahasan mengenai teori persepsi Mulla Shadra.Mengapa kesadaran mempelajari kesadaran?Pertanyaan ini lahir dari berbagai kemungkinan. Pertama, "kesadaran yang mempelajari" (subyek: S) identik dengan "kesadaran yang dipelajari” (obyek: O). Kedua, "kesadaran S" berbeda dengan "kesadaran O”. Maksudnya, tidak mungkin kesadaran seorang peneliti dapat memahami kesadaran orang lain. Ketiga, "kesadaran" esensinya tidak bisa dipelajari.Kesadaran memahami kesadaran adalab seperti 
lingkaran.Katakanlah kesadaran 1 mempelajari kesadaran 2, maka sebaliknya juga bisa demikian, kesadaran 2 mempelajari kesadaran 1.Demikian pula halnya terhadap kesadaran 3, 4, dan seterusnya. Lalu, kesadaran manakah yang sungguh-sungguh sebuah kesadaran murni yang menjadi subyek dan bukan obyek dari kesadaran yang lain? Karena tidak ada, maka menjadi tak mungkin bahwa kesadaran bisa mempelajari kesadaran lain karena yang terakhir ini bisa melakukan hal yang sama sehingga kesadaran yang pertama tidak lagi menjadi kesadaran yang murni subyek.

Lingkaran kesadaran mempelajari kesadaran itu dapat digambarkan sebagai berikut: Alternatif lain adalah regresi tiada henti (tasalsul) sehingga tidak jelas titik awal kegiatan penyelidikan itu:Husain Di sini kita seakan dihadapkan pada dilema, yakni apakah kesadaran mempelajari kesadaran itu hal yang tak mungkin ataukah suatu hal yang mungkin terjadi. Jika kita pilih yag pertama, bagaimana tentang kenyataan bahwa dalam kehidupan nyata sehari-hari, kita setiap saat selalu dalam upaya memahami dan menafsirkan kesadaran orang lain baik ketika berkomunikasi, mengajar, berdiskusi, berdebat maupun ketika membaca buku-buku atau tulisan-tulisan yang merupakan produk kesadaran orang lain. Jika kesadaran kita tidak mungkin memahami kesadaran orang lain termasuk produk-produknya (lisan, tulisan), maka tentu tidak akan ada pengetahuan apapun, bukan hanya psikologi tetapi seluruh pengetahuan menjadi tak bermakna atau kehilangan basis legitimasi kebenaran. Sebaliknya, jika kita pilih yang kedua, bagaimana kita menjawab persoalan lingkaran dan regresi tak berhingga kesadaran tersebut.

\section{Keniscayaan Ilmu Hudhuri sebagai Basis seluruh Pengetahuan}

Refleksi kritis Prof. Hamdi Muluk di muka justru merupakan pintu masuk bagi Mehdi Ha'iri Yazdi dalam membuktikan keniscayaan ilmu +udhûrî (knowledge bypresence, pengetahuan presensial). Dalam karya masterpiece-nya, The Principles ofEpistemology in Islamic Philosophy: Knowledge by Presence (1992), Mehdi menjelaskan bagaimana ilmu +udbûrî merupakan basis konstitusi bagi seluruh jenis dan modus pengetahuan manusia. ${ }^{10}$ Tanpa pengakuan adanya ilmu + udhôrî ini, maka seluruh konsep dan pengetahuan akan kehilangan pijakan realitas. Secara analitis, Mehdi menyusun argumen sebagai berikut: S mengetahui P P adalah proposisi "Air akan mendidih jika dipanaskan" Pengetahuan S tentang $\mathrm{P}$ hanya bermakna jika pengertian konsep-konsep beserta relasi antar konsep-konsep tersebut hadir dalam kesadaran S dan S memiliki kesadarandiri. Kehadiran konsep-konsep dalam kesadaran itulah yang merupakan basis pengetahuan.

Mehdi juga mengulas secara ekstensif karakteristik pengetahuan presensial ini, diantaranya mengelaborasi dimensi empiris pengetahuan presensial.Dia membuktikan bahwa kesadaran tentang persepsi indrawi dan perasaan kita merupakan sebuah bentuk pengetahuan presensial.Pernyataan "Saya sakit" adalah pengalaman langsung yang dirasakan dan diekspresikan seseorang tanpa mediasi, refleksi, representasi dan perantara konsep-konsep.Tidak ada kriteria benar-salah dalam pengalaman ini; yang ada adalah intensitas rasa sakit.Jadi, tidak ada dualisme atau dikotomi korespondensional dalam pengalaman ini.Konsep-konsep dikotomis seperti benarsalah muncul kemudian ketika rasa sakit itu ditafsirkan atau didiagnosa

${ }^{10}$ Lihat Mehdi Ha'iri Yazdi, The Principles of Epistemology in Islamic Philosophy: Knowledge by Presence (New York: SUNY Press, 1992), 57. 
oleh seorang dokter.Konsep-konsep inilah yang tergolong ilmu +ushûlî (knowledge bycorrespondence, knowledge by concept)..$^{11}$

Jadi, pertanyaan yang dikemukakan oleh Prof. Hamdi Muluk tentang kesadaran di muka adalah disebabkan beliau memahami kesadaran sebagai pengetahuan konseptual yang merepresentasikan sesuatu, yang tentu saja akan melahirkan regresi tak hingga. Mehdi menulis, Apa yang kita kenal dan hadir dalam diri kita mestilah dalam dirinya sendiri

merupakan "sesuatu" yang langsung diketahui, bukan melalui "representasi". Sebab, jika setiap yang kita ketahui adalah representasi yang kemudian mesti kita kenali, akan menjadi sebuah regresi tak terhingga (an infinite regression) dalam jajaran pengenalan dan representasi. Untuk mengakhiri jajaran representasi itu, pengenalan asli yang pertama hendaknya tidak dicapai melalui pengenalan lain atau representasi; tetapi mesti dicapai melalui kehadiran. ${ }^{12}$

\section{Teori Persepsi Mullâ Shadrâ}

Mullâ Shadrâ adalah salah seorang filsuf Islam yang paling intensif mengulas tentang persepsi. Dengan sistem filsafat baru yang dia bangun, yaitu filsafat transendental (al-ikmah al-mutáâliyyah), melalui sintesis kreatif mazhab-mazhab filsafat Peripatetik, Iluminasionis, dan Gnosis ('irfân), Shadrâ menyuguhkan analisis yang komprehensif, mendalam, dan elaboratif terhadap isu-isu pengetahuan, termasuk mengenai persepsi. Berbeda dengan mazhab-mazhab filsafat sebelumnya, pengetahuan, menurut Shadrâ, merupakan modus eksistensi (al-ílm na-w al-wujûd). Oleh karena itu, sesuai dengan prinsip gradasi eksistensi (tasykîk al-wujûd), pengetahuan juga memiliki level-level tahapan.Untuk melihat lebih jelas posisi penting isu persepsi diperlukan pengantar secara ringkas tentang prinsip-prinsip epistemologi Shadrâ. Setelah itu akan dipresentasikan implikasi teori persepsi Shadra terhadap psikologi secara epistemlogis dan metodologis. James W. Morris menulis, "The essential creativity of the soul(khallaqiyat al-nafs) in its acts of perception is one of the most basic principles of Sadra'sepistemology".13

\section{Prinsip-prinsip Epistemologi Mullâ Shadrâ}

Mullâ Shadrâ menyadari bahwa misteri hubungan antara pikiran dengan realitas luar di sekeliling kita merupakan salah satu isu terpelik dalam filsafat khususnya epistemologi.Dalam pandangan Shadrâ, misteri itu tidak dapat diselesaikan dalam matriks pengetahuan sebagai representasi. Kesulitan pokok bukan terletak pada jenis relasi apa yang terjadi, korespondensi atau koherensi, antara intelek dan obyek inteleksi.

Pokok persoalan itu adalah kemampuan jiwa (al-nafs) untuk mempersepsiintelligibles (ma'qûlât; obyek-obyek akal). Shadrâ mengutarakan kerisauannya mengenai ketidakjelasan karakteristik pengetahuan yang ditinggalkan para filsuf sebelumnya, Bahwasanya masalah tentang jiwa yang dapat memahami forma hal-hal intelligible(al-shuwar al-asy-yâa al-ma quîh) adalah sebuah persoalan filsafat yang paling pelik, yang belum satupun sarjana Islam hingga sekarang dapat memecahkannya.Ketika kami melihat kesulitan masalah ini dan merenungkan kemusykilan bahwa

${ }^{11}$ Yazdi, The Principles of Epistemology in Islamic Philosophy: Knowledge by Presence, 58

${ }^{12}$ Yazdi, The Principles of Epistemology in Islamic Philosophy: Knowledge by Presence, 58-59

${ }^{13}$ James W. Morris, The Wisdom of Throne: An Introduction to the Philosophy of Mulla Sadra (Princeton: Princeton University Press, 1981), 244. 
pengetahuan terhadap substansi adalah substansi dan aksiden, kami tidak menemukan penjelasan yang memadai pada buku-buku para filsuf termasuk pemimpin mereka Abû 'Alî (Ibn Sînâ) seperti al-Syifâ', al-Najâh, al-Isyârât, 'Uyûn al-*ikmah, dan lain-lain. ${ }^{14}$

Mullâ Shadrâ memulai pembahasan tentang pengetahuan dengan mengemukakan bahwa pengetahuan adalah sebuah modus eksistensi (al-ilm na-w minal-wujûd) yang identik dengan kehadiran; pengetahuan dan intelligibilitas termasuk bagian integral dari lautan eksistensi.Sebagaimana eksistensi yang memasuki segala sesuatu, pengetahuan juga hadir dalam seluruh kanal realitas dan maujud bahkan batubatu dan wadag-wadag material. Sesuai dengan prinsip gradasi eksistensi, pengetahuan dan inteleksi ditemukan dalam segala sesuatu dengan berbagai level intensitas dan realitas.

Di bawah sebuah sub-bab berjudul Penjelasan Makna Pengetahuan, Shadrâ menulis, Pengetahuan bukanlah sebuah penafian (amr salbi) seperti abstraksi (tajarrud)dari materi; ia juga bukan sebuah hubungan (idhâfah). Akan tetapi, ia adalah eksistensi. Dan ia bukan sembarang eksistensi melainkan eksistensi aktual (mujûdbil-fi'), bukan potensial. Dan bahkan ia tidak sembarang eksistensi aktual, namun eksistensi murni yang tidak bercampur dengan ketiadaan. Semakin murni ia dari ketiadaan semakin meningkat intensitasnya (syiddab) sebagai pengetahuan. ${ }^{15}$ Jadi, pengetahuan adalah wujud yang terbebas dari materi. ${ }^{16}$ Bantahan Shadrâ terhadap teori abstraksi, yang membuat pengetahuan menjadi kehilangan kualitas-kualitas eksistensial, didasarkan atas refleksi terhadap faktisitas kesadarannya sebagai berikut: Adalah kekeliruan yang nyata untuk mendefinisikan proses inteleksi (al-ta'aqqul) sebagai sebuah penafian (amr salbî; privation).Ketika kita menengok kesadaran kita dalam memikirkan sesuatu, kita temukan sesuatu telah terjadi dalam jiwa kita,bukan malah kehilangan sesuatu.Ketika kita mengetahui sesuatu setelah kita tidak mengetahuinya, pastilah ada sesuatu yang memiliki efek terhadap diri kita. Jika tidak, tentu keadaan kita akan tetap sama dengan sebelum dan selama mempersepsi sesuatu. Efek ini tidak lain dari persoalan eksistensial (amr wujudì). Kita mengetahui melalui kesadaran kita bahwa ketika kita mengetahui sesuatu, semacam penyempurnaan (amr kamalî) terjadi pada kita, dan bukan justru hilangnya sesuatu dari kita. ${ }^{17}$

Shadrâ mengganti pengertian tajarrud (abstraksi) dari isu negasi, eliminasi, pengurangan (privasi) menjadi isu eksistensial, peningkatan intensitas dan penyempurnaan.Pengetahuan bukanlah sesuatu yang bersifat negatif melainkan positif. Secara fenomenologis, Shadrâ menjelaskan bahwa ketika kita mengetahui sesuatu maka kita sadar akan sesuatu, dan itu bukanlah penegasian tetapi afirmasi. Ketika kita mengetahui hewan tertentu, misalnya, kita tidak menegasikan materi atau bentuk fisik darinya; sebaliknya, konsep hewan mencakup dimensi material.Ini menunjukkan bahwa abstraksi tidak berarti sebuah penafian dari apapun.Shadrâ melanjutkan uraiannya dengan menyodorkan sebuah proposisi, "A mengetahui B". Jika abstraksi dipahami sebagai sesuatu privasi, proposisi itu akan absurd jika dikatakan "A adalah abstrak untuk B" atau "B adalah abstrak untuk A". Karena, jika B adalah abstrak, maka ia akan abstrak

${ }^{14}$ Mullâ Shadrâ, al-Hikmah al-Muta áliyah fíl-Asfâr al-'Aqliyyat al-Arba'ah (Beirut: Dâr I-yâ al-Turâts al-'Arabî, 2002), Vol. 3, 247.

${ }^{15}$ Mullâ Shadrâ, al-Hikmah al-Muta'âliyah fi'l-Asfâr al-'Aqliyyat al-Arba'ah, 235.

${ }^{16}$ Mullâ Shadrâ, al-Hikmab al-Muta âliyah fi'l-Asfâr al-'Aqliyyat al-Arba'ah, 233

${ }^{17}$ Mullâ Shadrâ, al-Hikemah al-Muta 'âliyah fi'l-Asfâr al-'A qliyyat al-Arba'ah, 227. 
bagi siapapun. Akhirnya, "menjadi abstrak" tidak pernah "menjadi pengetahuan".Dengan demikian, pengetahuan bagi Shadrâ, alih-alih bersifat abstrak-negatif, adalah konkriteksistensial.Pengetahuan merupakan kualitas ontologis yang positif, keterisian, kepenuhan, dan penyempurnaan.

Dalam mengetahui sesuatu, kita mempersepsi, mengkonsepsi dan memperoleh suatu aspek tertentu dari eksistensi. Oleh karena eksistensi adalah yang paling konkrit, sempurna, dan aktual dari seluruh realitas, maka persepsi terhadapnya akan membawa status kesadaran yang lebih tinggi, yang sekali lagi, tidak ada tempat untuk negasi dan privasi. Sejalan dengan sistem ontologi eksistensialnya, Shadrâ juga menolak teori representasional yang hanya menganggap pengetahuan sebagai impresi mental.Secara praktis, Shadrâ bisa menerima aplikasi teori ini untuk tipe-tipe obyek tertentu yang meniscayakan relasi subyek-obyek, seperti pikiran dengan benda-benda material. Akan tetapi, secara prinsip, teori ini tidak bisa diterima karena ia tidak dapat diterapkan pada pengetahuan konseptual untuk konsep-konsep yang tidak termasuk dunia korporeal. Shadrâ mengajukan contoh tentang pengetahuan-diri yang tidak mungkin tergolong representasional.Dia menjelaskan, Mazhab yang berpandangan pengetahuan adalah forma yang tercetak dalam akal subyek (al-âqi) juga tak dapat diterima karena tiga alasan. Pertama, seandainya inteleksi (ta'aqqu) itu menghasilkan sebuah forma dalam subyek, maka kita tidak akan pernah memikirkan esensi diri kita sendiri. Tentu saja kesimpulan ini salah karena hal itu (pengetahuan-diri) adalah niscaya oleh kesadaran kita.

Refleksi-diri kita muncul dalam diri kita dari diri kita sendiri.Kedua, pengetahuan-diri itu adalah niscaya oleh keberadaan sesuatu yang tunggal sebagai substansi dan aksiden karena forma diri kita adalah esensi diri kita sendiri.Ketiga, seluruh forma mental adalah universal. Tetapi, kita tahu bahwa diri kita sendiri sebagai identitas partikular tanpa kemungkinan berbagi dengan subyek yang lain. Apapun yang ditambahkan kepada diri kita, kita menyebutnya sebagai 'ia' (buwa), sementara kita mengacu diri kita sendiri sebagai 'aku' (ana). Seandainya pengetahuandiri kita adalah melalui sebuah forma yang dilekatkan ke diri kita, kita akan menyebut diri kita sendiri sebagai 'ia'. Kesimpulannya adalah (teori mazhab ini) keliru. ${ }^{18}$ Sesuai dengan prinsip gradasi eksistensi, pengetahuan bagi Shadrâ juga gradual dan memiliki banyak level intensitas. Semakin kuat intensitas eksistensi semakin tinggi pula derajat pengetahuan.Shadrâ gigih menekankan bahwa pengetahuan bukanlah maujud material karena dalam maujud (eksisten) material kita absen dan tidak hadir.Misalkan kita memiliki sebuah obyek material di hadapan kita.

Obyek ini tersusun dari beberapa unsur material, masing-masing elemen ini absen satu sama lain, dan keseluruhannya absen dari bagian-bagiannya. Oleh karena itu, menurut Shadrâ, pengetahuan tidak mungkin sebuah eksisten material karena pengetahuan identik dengan kehadiran dan dalam entitas material kita absen. "Maujud-maujud material tidak hadir untuk mereka sendiri, lalu bagaimana mereka dapat mempersepsi yang lain”, tulis Shadrâ. Atas dasar refleksi ini pulalah Shadrâ menyatakan bahwa pengetahuan aktual terhadap sebuah obyek lebih intens dan tinggi daripada entitas obyek material.

Berikut saya paparkan beberapa karakteristik pengetahuan berdasarkan filsafat Mullâ

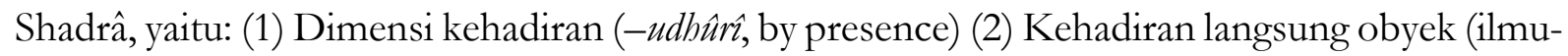

\footnotetext{
${ }^{18}$ Mullâ Shadrâ, al-Hikemah al-Muta âliyah fi'l-Asfâr al-'Aqliyyat al-Arba'ah, 229.
} 
dengan-kehadiran; al-ìlm al-udhûrì) (3) Kehadiran tak langsung obyek melalui forma (ilmudengan-konsep; al-ilm al-ushûli) (4) Kehadiran forma partikular (persepsi indrawi dan imajinal) (5) Kehadiran forma universal (persepsi intelektual) (6) Entitas non-material sebagai agen pengetahuan (immaterialitas pengetahuan) (7) Kesatuan subyek-obyek adalah instanta paling sempurna dari kehadiran Pengetahuan dalam sistem epistemologi Mullâ Shadrâ terbagi ke dalam dua bagian pokok, yaitu 1. Ilmu-dengan-korespondensi (al-ilm al-ushâlli knowledge by correspondence) 2.Ilmu-dengan-kehadiran (al-ilm al-udbûrî; knowledge by presence) Ilmudengan-korespondensi (pengetahuan konseptual) adalah pengetahuan tentang dunia eksternal yang diperoleh melalui kuiditas-kuiditasnya (mâhiyyât) tanpa kehadiran eksistensi eksternal beserta efek-efek eksternalnya.Pengetahuan jenis ini diperoleh melalui konsep-konsep sebagai representasi dunia luar sehingga dinamakan juga pengetahuan konseptual.Justifikasi pengetahuan ini dioperasikan dengan menguji hubungan koresponden antara dunia mental dan dunia eksternal; karena itu dinamakan juga pengetahuan-dengan-korespondensi.

Dua dunia yang berbeda ini secara eksistensial absen dari, dan tidak hadir atau bersatu dengan, yang lain. Shadrâ menolak kemungkinan terjadinya perubahan dan peleburan (inqilab) kedua identitas ini satu sama lain, "Kehadiran forma perseptual pada subyek (yaitu jiwa) berbeda dengan realitas aktualnya pada materi." Ilmu-dengan-kehadiran (pengetahuan presensial) adalah pengetahuan tentang sesuatu yang hadir langsung pada subyek tanpa perantara, mediasi, dan konsep. Kesadaran-diri hadir pada diri kita tanpa kuiditas diri; ia tidak hadir sebagai konsep atau diketahui melalui perantara. Pengetahuan kita tentang diri kita sendiri hadir dengan eksistensi eksternalnya (wujûd al-khârijî) sendiri.

Pengetahuan nonrepresentasional ini bersifat eksistensial dan primordial, dalam arti ia merupakan basis konstitusi bagi seluruh jenis dan modus pengetahuan manusia. Shadrâ memberikan penjelasan tentang keniscayaan hadirnya pengetahuan-presensial dalam setiap bentuk pengetahuan bahwa seluruh persepsi indrawi, imajinasi dan inteleksi mensyaratkan adanya kesadaran dasar tentang eksistensi diri.Shadrâ berargumen, Setiap kejadian fenomenal yang saya nisbatkan kepada diri saya, misalnya merasa dingin, hangat atau sakit, harus, dan memang, mempraanggapkan adanya kesadaran dasar tentang diri saya.Dengan kesadaran dasar ini, saya bisa menghadirkan dalam diri saya rasa dingin, panas, sakit, senang, dan lain-lain. Jika saya menderita karena udara yang sangat dingin atau menghindar dari panas nyala api, itu hanya karena saya telah sadar akan sesuatu yang, dengan cara tertentu, ada dalam diri saya. Muhammad Taqi Misbah Yazdi ${ }^{19}$ mengidentifikasi empat jenis pengetahuan dan kesadaran yang tergolong pengetahuan-presensial, yaitu : 1. Pengetahuan-diri 2. Kesadaran terhadap keadaan psikologis 3.Kesadaran diri mengenai fakultas-fakultas perseptual dan motorik 4. Kehadiran forma-forma dan konsep-konsep mental dalam akal.

\section{Prinsip-prinsip Pokok Teori Persepsi Mulla Shadra}

Uraian di muka menggambarkan pentingnya pengetahuan presensial dalam sistem epistemologi Mullâ Shadrâ sebagai batu pijakan semua jenis dan level pengetahuan.Pengetahuan

${ }^{19}$ Taqi Misbah Yazdi, Philosophical Instructions: An Inroduction to Contemporary Islamic Philosophy (translated by M. Legenhausen dan 'Azim Sarvdalir) (New York: Binghamton University, 1999), 103-104. 
konseptual pun membutuhkan kehadiran pengetahuan-diri sebagai basis ontologis. Sementara itu, salah satu modus pengetahuan presensial adalah kesadaran akan fakultas perseptual. Kesadaran kita akan fakultas perseptual bersifat nonrepresentasional, langsung, hadir, dan tanpa forma dan konsep apapun selama tindakan persepsi itu berlangsung. Misalnya, kita sadar bahwa indra mata kita memandang suatu obyek dan obyek itu hadir di hadapan kita, terlepas nanti apakah penafsiran terhadap obyek persepsi itu benar atau keliru. Kesadaran ini bersifat primordial, mendahului segala konsep dan putusan.Oleh karena itu, kesadaran ini termasuk pengetahuan presensial.Mengingat pengetahuan presensial yang eksistensial, positif, dan substantif merupakan doktrin pokok epistemologi Shadrâ, maka isu persepsi menjadi salah satu pembahasan yang banyak dianalisis oleh Shadrâ.Secara konsisten Shadrâ mendiskusikannya di sejumlah karyanya termasuk di beberapa volume buku utamanyaal-Asfâr ( 9 jilid).

Sayyid Muhammad Khamenei menyebut teori persepsi Shadrâ sebagai teori yang lebih akurat dan komprehensif dari para filsuf lainnya. ${ }^{20} \mathrm{Lalu}$, apakah persepsi itu menurut Shadrâ? Dimana letak pentingnya isu persepsi dalam sistem pemikirannya secara umum?Bagaimana dia menyusun teorinya mengenai persepsi secara sistematis?Pertama-tama, Shadrâ menyebutkan kesatuan makna persepsi (al-idrâk) dengan pengetahuan (al-ílm) sejauh diterapkan terhadap modus-modus persepsi seperti inteleksi (al-ta'aqqul), imajinasi (al-takhayyul), dan indrawi $(a l-i-s \hat{a} s) .{ }^{21}$ Di tempat lain, Shadra menyebut sebuah jenis persepsi lain, yaitu estimasi (al-tawabhum).

Masing-masing ketiga persepsi pertama berhubungan dengan level eksistensi, sedangkanpersepsi estimasi seperti halnya imajinasi berada di antara alam indrawi dan alam intelek.Shadrâ mendefinisikan persepsi sebagai "pertemuan" (al-liqâ) dan "pencapaian" (alwushûh) lalu menjelaskan "ketika fakultas intelek (al-âqỉ) mencapai kuiditas obyek (al-ma'qûl) dan mencerapnya, itulah persepsi dari aspek ini". ${ }^{22}$ Shadrâ menyebutkan definisi ini sebagai makna terminologis dalam filsafat. Dia melanjutkan, "Persepsi dan pertemuan yang real tidak lain adalah 'pertemuan' itu sendiri, yaitu persepsi pengetahuan (al-idrâk al-ílmî).

Subyek yang aktif bekerja dalam tindakan persepsi adalah jiwa (al-nafs), yang bergerak dari satu level eksistensi ke level yang lain. Jika persepsi itu terjadi pada level indrawi maka jiwa mempersepsinya sebagai obyek indrawi; jika terjadi pada level imajinatif maka jiwa mempersepsinya sebagai obyek imajinatif, dan pada level intelektif jiwa mempersepsi sebagai obyek-akal (ma'qûl; intelligible) atau universal.

Obyek-obyek eksternal yang berkoresponden dengan organ-organ indrawi seperti penglihatan, pendengaran, dan penciuman berperan sebagai persiapan dan penyedia "kesempatan" untuk penciptaan forma perseptual oleh jiwa ketika kondisikondisi persepsi terwujud. Shadrâ memberi contoh bagaimana indra mata secara pasif menerima stimulus cahaya akan tetapi ia tidak mempersepsinya sebagaimana jiwa mempersepsi kualitas-kualitas eksistensial obyek bercahaya tersebut. ${ }^{23} \mathrm{Jadi}$, subyek persepsi adalah jiwa; tindakan persepsi dilakukan oleh

\footnotetext{
${ }^{20}$ Sayyid Muhammad Khamenei, Mulla Sadra's Transcendent Philosopby (Tehran: SIPRIn, 2003), 91.

${ }^{21}$ Mullâ Shadrâ, Asfâr, Vol. 3, 233.

${ }^{22}$ Mullâ Shadrâ, Asfâr, Vol. 3, 396

${ }^{23}$ Mullâ Shadrâ, Asfâr, Vol. 8, 195.
} 
jiwa; dan obyek persepsi adalah forma yang diciptakan oleh jiwa melalui stimulus eksternal dalam konteks pengetahuan eksternal.Di satu sisi, Shadrâ menekankan pentingnya pengalaman langsung dengan obyek eksternal dalam tindakan persepsi.Namun, di lain sisi, Shadrâ menyatakan bahwa seluruh jenis persepsi dilakukan oleh jiwa dan bersifat immaterial. ${ }^{24}$ Tindakan persepsi itu sendiri merupakan sebuah unifikasi (al-itti-âd) antara subyek yang mempersepsi (mudrik) dan obyek persepsi (mudrak).Obyek persepsi yang dimaksud adalah forma perseptual yang terdapat dalam jiwa.

Penyatuan yang dimaksud adalah proses identiknya subyek dengan obyek pada tataran eksistensi; jadi, ia bukan penggabungan dua entitas. Hal ini berlaku pada semua jenis persepsi. ${ }^{25}$ Karakteristik penting lain dari teori persepsi Shadrâ adalah hubungan aktivitas persepsi dengan gerak penyempurnaan dan peningkatan intensitas jiwa secara substansial. Persepsi dan pengetahuan bukan suatu atribut yang ditanam atau dicangkok ke dalam jiwa.Akan tetapi, proses dan hasil persepsi turut mengonstitusi dan mengubah substansi jiwa.Ini adalah implikasi dari prinsip ontologis gerak transsubstansial. Jadi, tindakan persepsi bagi Shadrâ bukan hanya sebatas memahami realitas akan tetapi lebih sebagai bagian dari proses mengada.

\section{Implikasi Epistemologis Persepsi Shadra untuk Psikologi}

Setelah kita mengelaborasi secara ringkas tapi padat mengenai prinsip-prinsip pokok teori persepsi Mullâ Shadrâ, maka kini kita perlu menguraikan implikasi epistemologisnya untuk studi psikologi (khususnya psikologi Islam) baik dalam riset maupun pengembangan konsepkonsep dasar.Jelaslah tampak sekali bagaimana Mullâ Shadrâ memosikan jiwa sebagai agen yang bertindak langsung dan hadir dalam seluruh aktivitas persepsi, yaitu pengindraan, imajinasi, dan inteleksi.Adalah jiwa yang hadir langsung dalam melihat, mendengar, merasakan, mencium, dan menyentuh obyek-obyek indrawi.

Pandangan Shadrâ ini mungkin berseberangan dengan anggapan umum yang tidak menyadari aktivitas jiwa dalam kontaknya dengan dunia korporeal sehari-hari. Shadrâ menjelaskan,

Jiwa meliputi seluruh fakultas (al-nafs kulli al-quwâ), artinya adalah bahwa subyek persepsi (al-mudrik) yang melakukan seluruh persepsi yang terkait dengan fakultas-fakultas manusia adalah jiwa rasional (al-nafs al-nâthiqah). Ia adalah penggerak seluruh gerakan yang muncul dari fakultasfakultas hewani, nabati, dan fisik manusia. Ini adalah sebuah persoalan utama dan terdapat banyak demonstrasi (argumen), sebagian dari aspek persepsi dan sebagian lainnya dari aspek gerak. ${ }^{26}$ Agar kita memperoleh pemahaman yang lebih utuh, mari kita simak bagaimana Shadrâ membangun argumen intinya tentang teori persepsi beliau bahwa jiwa merupakan agen tunggal dalam seluruh tindakan kognisi pada setiap level. Yang menarik adalah Shadrâ memulai pembuktian pernyataan tersebut secara fenomenologis dengan menyibak pengalaman keseharian kita yang tenggelam dalam rutinitas untuk menyadari bahwa jiwa rasional kita sebetulnya telah bekerja meski kita tidak menyadarinya,

\footnotetext{
${ }^{24}$ Mullâ Shadrâ, Asfâr, Vol. 3, hal. 235.

${ }^{25}$ Mulla Shadrâ. Kitâb al-Masyâ ir (Beirut, 2000), 101. Bdk. Mullâ Shadrâ. Kitâb al-Masyâ ir, (New York, 1992), Prehensi Pertama, Proposisi 112, 64.

${ }^{26}$ Mullâ Shadrâ, Asfâr, Vol. 8, hal. 193.
} 
Argumen pertama: dari aspek obyek pengetahuan (al-malum). Adalah mungkin bagi kita untuk memberikan putusan tentang sesuatu dengan sifat-sifat pokok obyek-obyek indrawi, estimatif, dan akal.Kita katakan, sebagai contoh, bahwa sesuatu yang memiliki warna itu mempunyai rasa tertentu; sesuatu yang memiliki suara seperti itu mempunyai aroma tersebut.

Di sini harus ada hakim (pembuatkeputusan) di antara dua hal tersebut untuk menghadirkan keduanya, dan juga harus ada pemberi afirmasi kedua konsep tersebut.Maka, di sini harus ada sebuah fakultas yang mempersepsi seluruh obyek-obyek indrawi (al-ma-sûsât) sedemikian sehingga mungkin bagi kita untuk memutuskan bahwa warna ini adalah makanan ini, dan bahwa yang memiliki suara itu beraroma seperti itu.Juga,jika kita imajinasikan sebuah forma, misalnya Zayd, dan lalu kita mempersepsinya dengan penglihatan, maka kita memutuskan bahwa forma itu adalah forma (indrawi) Zayd.

Oleh karena itu, harus ada sebuah fakultas yang mempersepsi forma imajinatif dan forma indrawi sehingga mungkin baginya untuk memutuskan bahwa forma dalam imajinasi ini berkoresponden dengan forma indrawi ini.Hakim itu mestilah fakultas yang mempersepsi makna-makna dan forma-forma.Ketika kita melihat Amir, dan memutuskan bahwa dia adalah seorang manusia atau hewan rasional dan bukan sebuah batu, bukan pohon, maka kita menilai obyek indrawi partikular dengan obyek akal universal.Oleh karena itu, ada pada kita satusatunya fakultas yang mempersepsi (subyek persepsi) obyek-obyek akal universal dan indrawi partikular; dan fakultas itu adalah jiwa, yang menjadi subyek seluruh jenis persepsi. ${ }^{27}$ Kemudian, Shadrâ melanjutkan argumennya dari aspek subyek pengetahuan (al-âlim) sebagai berikut, Anda tidak ragu bahwa anda melihat segala sesuatu, mendengar suara-suara dan mempersepsi obyekobyek akal (al-ma'qûlât; intelligibles). Anda tidak ragu bahwa anda adalah satu secara bilangan. Jika yang mempersepsi intelligibles adalah bukan yang mempersepsi obyek-obyek indra, maka substansi dzat anda yang adalah "anda", berdasarkan penyelidikan, tidak akan mempersepsi kedua jenis obyek itu bersamaan. Jika anda mempersepsi kedua obyek itu bersamaan maka anda adalah satu dzat (esensi) yang adalah subyek persepsi kedua obyek itu. Jika tidak demikian, anda akan menjadi dua esensi dan bukan satu esensi.

Hal yang samamengenai fakultas syahwat (seks) dan amarah; tidak ada keraguan bahwa anda sebagai subyek keinginan seks atau sesuatu yang lain, dan anda juga subyek yang

berang pada musuh anda. ${ }^{28}$ Uraian di muka hendak menunjukkan keniscayaan adanya satu fakultas umum (yaitu jiwa) yang menyatukan seluruh jenis persepsi, keadaan mental psikologis dan fakultas motorik. Lalu, Shadrâ membuka sebuah perdebatan, Jika anda berkata bahwa fakultas penglihatan (al-qumwah al-bâshirah), yaitu mata, adalah organ yang mempersepsi obyekobyek penglihatan, lalu ia mentransfer apa yang ia terima kepada anda melalui sebuah koneksi antara ia dan anda, maka anda memperoleh kesadaran terhadap sesuatu yang telah dipersepsi oleh fakultas penglihatan. Kami akan bertanya, setelah ditransfer kepada anda, apakah anda mempersepsi kembali obyek penglihatan tersebut sebagaimana organ telah

Husain Heriyanto mempersepsinya atau tidak? Jika anda berkata "ya", maka persepsi anda adalah suatu hal dan persepsi organ anda adalah hal yang lain. Maka, bangunlah! Persepsi anda

\footnotetext{
${ }^{27}$ Mullâ Shadrâ, Asfâr, Vol. 8, 193-194.

${ }^{28}$ Mullâ Shadrâ, Asfâr, Vol. 8, 195.
} 
bergantung kepada persepsi organ anda, tetapi sesungguhnya andalah subyek yang mempersepsi dan itulah mengapa persepsi itu telah diperoleh untuk anda dan bukan karena persepsi itu telah diperoleh untuk organ anda. ${ }^{29}$ Shadrâ memandang orang-orang yang merasa bahwa organorgan indrawinyalah yang hadir untuk mempersepsi sebagai orang yang jiwanya tertidur.Dia melanjutkan diskusinya, Jika anda berkata bahwa anda tidak mempersepsi setelah transfer itu, maka dalam kasus itu anda belum melihat, atau mendengar, dan anda tidak mengalami rasasakit anda, kesenangan anda, lapar anda, dan haus anda.Tidak demikian halnya; anda selama ini belajar bahwa mata adalah organ anda dan fakultas penglihatan telah mempersepsi dan melihat sesuatu. Pengetahuan (yang anda pelajari) iniadalah suatu hal dan realitas penglihatan adalah hal lain. Pengetahuan yang mata lihat, telinga dengar, kaki berjalan, dan tangan memukul bukanlah penglihatan, pendengaran, berjalan, dan memukul.Tetapi, orang-orang berakal mengetahui bahwa merekalah yang mendengar, mereka yang melihat; bahwa mereka yang merasakan sakit, menikmati kesenangan, mereka yang berjalan, dan mereka yang memukul. ${ }^{30}$ Shadrâ terus mengupas kesadaran reflektif di balik keseharian kita sampai tiba pada kesimpulan "substansi jiwa anda yang dengannya anda adalah "anda" adalah subyek pendengar, penglihat; subyek yang sakit, gembira, berpikir, memahami, pemukul, dan pejalan kaki.Shadrâ melanjutkan argumennya, Argumen ketiga adalah dari aspek pengetahuan (al-ílm).

Jiwa adalah subyek yang mempersepsi partikular-partikular.Tidak ada keraguan bahwa jiwa adalah suatu esensi individual dan terkoneksi dengan badan, yang adalah sebuah koneksi yang terkait dengan pengelolaan badan. Diketahui bahwa sebuah jiwa partikular tidak akan menjadi manajer badan universal kecuali ia menjadi intelek universal yang immaterial. Oleh karena itu, jiwa adalah manajer suatu badan partikular.Itu hanya mungkin dengan kehadiran forma individualnya di hadapan jiwa. Hal ini meniscayakan jiwa untuk menjadi subyek yang mempersepsi hal-hal particular dan sekaligus hal-hal yang universal. ${ }^{31}$ Shadrâ masih memiliki banyak argumen, yang tidak mungkin semuanya dipaparkan di sini, untuk membuktikan dan membangunkan kesadaran kita bahwa jiwa adalah subyek yang mempersepsi seluruh jenis dan tingkatan persepsi.Shadrâ mengindikasikan kuatnya hubungan antara jiwa dan badan tetapi hubungan keduanya bukanlah hubungan dua kategoris, melainkan hubungan dua modus eksistensi di mana jiwa adalah agen aktif yang melahirkan pengertian, forma perseptual dan pengetahuan sedangkan badan berperan sebagai organ aksiden yang melaluinya jiwa mengaktualisasikan diri.

\section{Implikasi Metodologis Teori Persepsi Mullâ Shadrâ untuk Psikologi}

Ulasan gamblang di atas dengan mengemukakan argumen-argumen Mullâ Shadrâ tentang peran sentral jiwa sebagai agen tunggal dalam seluruh tindak kognisi dan persepsi manusia, maka dapat kita katakan bahwa fokus riset dan pendekatan yang disarankan oleh Shadrâ untuk psikologi adalah bagaimana membangunkan jiwa agar aktif dan kreatif. Jiwa memiliki kapasitas untuk menciptakan dunia perseptual.

\footnotetext{
${ }^{29}$ Mullâ Shadrâ, Asfâr, Vol. 8, 195.

${ }^{30}$ Mullâ Shadrâ, Asfâr, Vol. 8, 195-196.

${ }^{31}$ Mullâ Shadrâ, Asfâr, Vol. 8, 196.
} 
Ketika mempersepsi benda ini dan kita katakan "ini bunga mawar", kita secara simultan telah menggunakan persepsi indrawi (melihat, memegang), persepsi imajinatif (menggunakan memori pengalaman lalu tentang bunga mawar partikular), persepsi intelektif (menangkap kuiditas, konsep universal "bunga"). Ketiga level persepsi tidak mungkin dilakukan oleh fakultasfakultas terpisah (organ indra, memori, akal). Jiwalah yang melakukan semuanya secara serentak.Jiwa dengan fakultas intelek juga dengan aktif dan kreatif menciptakan formaforma perseptual, berdasarkan bahan mentah yang dipasok oleh pengalaman langsung jiwa dalam kontaknya dengan obyek-obyek eksternal. Bagi Shadrâ, organ indrawi penting sebagai persiapan dan penyedia bagi jiwa untuk mempersepsi, yang kemudian setelah melalui proses dari indrawiimajinasi-inteleksi, jiwa membangkitkan (tsubût) forma-forma perseptual. Forma perseptual yang merupakan bagian substansial eksistensi mental inilah yang disebut dengan pengetahuan kita tentang realitas eksternal korporeal.

Shadrâ mengungkapkan kemampuan kreatif akal ini, Sesungguhnya forma materi yang yang besar tidakakan muncul pada materi kecil; tidak mungkin gunung tertampung oleh debu; tidak mungkin juga samudera tertampung oleh kolam. Namun, hal itu berbeda dengan eksistensi persepsi (alwujûd al-idrâkî) karena jiwa dapat menampung yang besar dan yang kecil. Jiwa

memiliki kemampuan berimajinasi untuk menghadirkan sekaligus forma langit dan bumi beserta diantara keduanya dalam sekejap tanpa kehilangan satupun darinya, sebagaimana yang telah digambarkan Sayyidina Muhammad SAW, "Sesungguhnya hati mukmin lebih besar dari "Arsyi”" (inna qalbu al-mu'min a'zhammin al-'Arsyl). Itu hanya dimungkinkan karena jiwa tidak memiliki ukuran dan tempat sehingga bisa menampung segalanya (pada tatanan eksistensi persepsi eksistensi mental yang ia ciptakan). ${ }^{32}$

Bagi Mullâ Shadrâ, persepsi bukanlah sebuah pencerminan forma segala sesuatu pada jiwa dengan posisi jiwa yang memiliki peran pasif dalam tindakan pengetahuan. Tetapi, persepsi juga bukan sebuah transfer jiwa ke dunia lain. Yang benar adalah jiwa manusia memiliki kekuatan kreatif dalam menciptakan forma-forma.Dalam konteks ini, jiwa mirip Allah yang menciptakan segala sesuatu tanpa batas meski dengan catatan bahwa level eksistensi jiwa lebih rendah sehingga ciptaannya tidak memiliki efek eksternal. Dalam pandangan Shadrâ, persepsi adalah sebuah aktivitas yang mentransformasi subyek dan obyek persepsi sekaligus. Persepsi bukanlah sebuah kejadian yang menimpa kita melainkan apa yang kita pikirkan, rasakan, dan lakukan.

Tindakan persepsi menggerakkan dan mengubah status keberadaan beserta cara berpikir dan cara bertindak diri kita. Melalui persepsi, obyek mengalami status ontologis yang baru dari maujud eksternal yang tidak hadir menjadi maujud mental yang hadir bersama subyek. Dalam konteks ini, Shadrâ mengkritik teori representasi yang umumnya dianut oleh para filsuf dan sarjana naturalis bahwa persepsi berlangsung melalui abstraksi negatif.Shadrâ menulis, Persepsi indrawi, dalam makna mutlak, tidaklah berlangsung sebagaimana anggapan masyhur di kalangan banyak filsuf.Mereka berpandangan bahwa fakultas persepsi mengabstraksi (tajrid) forma persepsi sebagaimana adanya dari materi berikut aksiden-aksiden yang tercakup di dalamnya.Lalu, imajinasi melanjutkan abstraksi tersebut. Tetapi, Anda sudah ketahui kemustahilan mentransfer cetakan ini (dari organ indra ke imajinasi, dan lalu ke intelek). Alih

\footnotetext{
${ }^{32}$ Mullâ Shadrâ, Asfâr, Vol. 3, 238
} 
alih demikian, persepsi -dalam makna mutlak- terjadi karena pemberi forma memancarkan (faydh, emanasi) forma perseptual bercahaya sedemikian sehingga persepsi dan kesadaran berlangsung. Forma ini adalah indra aktual (al-âssab bi-lfi't) dan sekaligus obyek-terindra aktual (al-ma-sîsah bi-l-fíc). Sedangkaneksistensi forma dalam materi bukanlah indra atau terindrai, melainkan hanyalah persiapan atau kondisi untuk terjadinya emanasi forma (dari jiwa). ${ }^{33}$ Penolakan Shadrâ terhadap teori representasi didasarkan atas pendiriannya tentang cara kerja jiwa dalam mempersepsi. Bagi Shadrâ, jiwa tidak pasif hanya menerima forma-forma, melainkan aktif mencipta dan menjadi satu dengan formaforma itu.

Proses menjadi ini tidak hanya berlaku secara temporer selama persepsi berlangsung melainkan mendenotasikan level-level baru eksistensi yang jiwa capai. Gerakan dan perubahan itu tidak terjadi pada tatanan pengertian (esensi) dari materi ke indra, lalu dari indra imajinasi, dan lalu dari imajinasi ke intelek tanpa gerakan dan perubahan subyek. Tidak mungkin ada gerakan pada tatanan esensi.Gerakan dan perubahan itu terjadi pada tatanan eksistensi. Baik subyek persepsi (al-mudrik) maupun obyek persepsi (al-mudrak) mengalami perubahan dari satu eksisten ke eksistensi lain, berjalan dari satu modus eksistensi ke modus yang lain dan dari satu dunia ke dunia yang lain, sehingga jiwa menjadi suatu intelek ('aq), intelijen ('âqi), dan intelligible (ma'qûh) yang aktual setelah sebelumnya semua hanya potensial. ${ }^{34}$

\section{Penutup}

Uraian di muka yang memaparkan prinsip-prinsip pokok teori persepsi Mullâ Shadrâ telah membawa kita kepada suatu kesadaran baru bahwa kita selama ini seakan tertidur karena tidak menyadari bahwa segenap tindakan kita termasuk persepsi indrawi merupakan aktivitas jiwa kita secara langsung. Implikasi epistemolois dan metodologis teori persepsi Shadrâ ini berpotensi untuk melakukan sebuah revolusi dalam psikologi, yaitu menghidupkan kembali yang hidup, yaitu jiwa selaku agen tunggal-holistik dalam seluruh tindakan kognisi dan persepsi kita, yang sayangnya agen tunggal ini selama ini justru diabaikan dan bahkan dianggap tidak penting atau tidak ada.

\section{DAFTAR PUSTAKA}

Carlson, Neil R. Psychology: The Science of Behavior. Massachusetts: Allyn and Bacon. 1993.

Eysenck,Michael W. Principles of Cognitive Psychology. East Sussex: Psychology Press. 2001. Neil R. Carlson, Psychology: The Science of Behavior.1993.

Feldman, Robert S. Essentials of Understanding Psychology.New York: Mc Graw-Hill, 2005. Yazdi, Mehdi Ha'iri .The Principles of Epistemology in Islamic Philosophy.Knowledge by Presence: New York: SUNY Press, 1992.

Morris,James W,The Wisdom of Throne: An Introduction to the Philosophy of Mulla Sadra,Princeton: Princeton University Press,1981.

Mullâ Shadrâ, al-Hikmah al-Muta'âliyah fi'-Asfâr al-'Aqliyyat al-Arba'ah, Beirut: Dâr Ihyâ al-Turâts al-'Arabî, 2002. 
Yazdi,Taqi Misbah.Philosophical Instructions: An Inroduction to Contemporary Islamic Philosophy, translated by M. Legenhausen dan 'Azim Sarvdalir, New York: Binghamton University, 1999.

Khamenei, Sayyid Muhammad, Mulla Sadra's Transcendent Philosophy, Tehran: SIPRIn, 2003. Mulla Shadrâ.Kitâb al-Masyấir, Beirut, 2000.

Mullâ Shadrâ.Kitâb al-Masyấir, New York, 1992. 